\title{
Sand bag barriers for coastal protection along the Emilia Romagna littoral, Northern Adriatic Sea, Italy
}

\author{
Luca Martinelli ${ }^{\mathrm{a}, \mathrm{b}, *}$, Barbara Zanuttigh ${ }^{\mathrm{a}}$, Nunzio De Nigris ${ }^{\mathrm{c}}$, Mentino Preti ${ }^{\mathrm{c}}$ \\ ${ }^{a}$ DICAM Idraulica, University of Bologna, Viale Risorgimento 2, 40136 Bologna, Italy \\ ' IMAGE, University of Padova, Via Ognissanti 39, 35129 Padova, Italy \\ ${ }^{\mathrm{c}}$ ARPA, Largo Caduti del Lavoro, 40122 Bologna, Italy
}

\section{A R T I C L E I N F O}

\section{Article history:}

Received 4 January 2010

Received in revised form

24 October 2010

Accepted 7 November 2010

Available online 15 January 2011

\section{Keywords:}

Sand bag

Coastal protection

Low crested structures

Submerged barriers

\begin{abstract}
A B S T R A C T
Beach nourishments protected by submerged sand bag barriers have been largely used in Emilia Romagna (Italy), whose low and sandy coast faces the relatively mild Northern Adriatic Sea. The paper, after a brief description of the eight projects of this type realised in the last 25 years along the Emilia Romagna littoral, details the case study of Riccione Southern beach. The performance of the defence is described by means of cross-shore profiles, bathymetries, collection of sediment samples, underwater pictures, monitoring of environmental conditions and performed maintenance. The combined analysis of the available data suggests that the sand bag barrier may stabilise the position of the natural sandy bar and ultimately the beach profile.
\end{abstract}

(C) 2010 Elsevier Ltd. All rights reserved.

\section{Introduction}

Major threats for large stretches of European coasts are erosion and flooding, which are mainly caused by: loss of river sediment load (due to hydraulic works, bridles, crossbars, dams, on rivers); subsidence (natural or anthropogenic, the latter due to extraction of water, gas, oil, etc.); inappropriate interception of long-shore transport (presence of hard defence, works and harbors along the coasts); dune decay (due to inappropriate management).

Effects of climate change, such as sea level rise and increasing frequency and intensity of storm events, concur in amplifying beach erosion and coastal vulnerability. Due to the low surface elevation and the increasing anthropogenic pressure (from 1950 to 2005 , the number of cities included in the coastal zone increased from 318 to 584; the population is forecasted to increase from 70 million-year 2000 to 90 million by 2025; data from Plan Bleu Report, 2008), the Mediterranean areas will be particularly stricken by climate change.

This picture points out the need of a strategic, sustainable and integrated management of the resource "sediment". It is noteworthy that the EC project EUROSION (www.eurosion.org) stressed

\footnotetext{
* Corresponding author. Tel.: +390498277996; fax: +390498277988.

E-mail addresses: luca.martinelli@unipd.it (L. Martinelli), barbara.zanuttigh@ unibo.it (B. Zanuttigh), ndenigris@arpa.emr.it (N. De Nigris), mpreti@arpa.emr.it (M. Preti).
}

both the "shortage of coastal sediments..." and the improperness of the "current Environmental Impact Assessment (EIA) practices..." in addressing coastal erosion matters.

The coast of the Emilia Romagna Region, in the Adriatic Sea, is an example of coastal zone with a series of erosive problems, accentuated by its long-term strong urbanization. The impact of this site for the Italian economy can be summarised with a few figures related to the tourism activities in the coastal municipalities for year 2006: 41 million of visitors/day in the period May-September, 3384 hotels, 154,000 employees and a gross income/year of 9.8 billion euros.

Indeed due to the strong economical importance of this site the Regional Administration has always been rather interested in coastal environmental issues. For instance, a pilot project was supported in Igea Marina beach consisting in the lowering of the existing traditional detached barriers, in order to improve beach quality despite an expected increase in the yearly sediment loss (Preti et al., 2005). A decadal coastal plan has been recently published (Preti et al., 2009), including two kinds of activities: 1) a series of general initiatives aiming to reduce the causes of erosion, to search new sediment stocks and to arrange an integrated management of these resources; 2) a series of guidelines for local and specific interventions, among which it is coherently suggested to avoid the building of traditional emerged structures in the perspective of more environmental-friendly solutions.

To cope with integrated coastal zone management issues, and particularly with environmental and aesthetic impact of coastal 
defence, the use of low crested structures and more specifically of geosynthetics for coastal protection has recently increased (Ruol and Matteotti, 2004; Saathoffa et al., 2007; Shina and Ohb, 2007; Recio and Oumeraci, 2007; Alvareza et al., 2007). Among these applications, a major role is played in Emilia Romagna by low sand bag barriers, that were built to protect eight beaches in the last 25 years (Liberatore, 1992). The advantage of making a barrier of sand bags compared to rock and concrete lies in a better resistance to sinking (the load is evenly distributed), and in the compactness of the final structure (the bags may deform and fill the empty spaces).

Aim of this paper is to describe the performance of sand bag barriers based on the experience along the Emilia Romagna coast, with particular reference to the case of Riccione Southern beach.

Section 2 presents the environmental conditions of the region and a brief description of the interventions here performed with sand bag barriers. Section 3 presents in details the case study of Riccione. Section 4 discusses the results and draws some general conclusions.

\section{Coastal defences along the Emilia Romagna littoral}

\subsection{Environmental conditions}

The Emilia Romagna littoral is located in the North East of Italy (Fig. 1) and comprises $130 \mathrm{~km}$ of low and sandy coast, 110 of which are strongly urbanized. The Adriatic Sea in this area has a maximum depth around $50 \mathrm{~m}$.

A general erosive tendency is mainly caused by the reduced sediment transport rates of the rivers, by the increased anthropogenic subsidence and by the strong anthropogenic pressure with building tourism facilities. The subsidence, mainly due to extractions of water and methane from subsoil, is constantly monitored and according to Preti et al. (2009) reaches the maximum value of $20 \mathrm{~mm} /$ year in front of Ravenna. Subsidence, eustatism and dune erosion pose a serious threat for coastal flooding (Martinelli et al., 2010).

The Coast Project showed that the Emilia Romagna region has the highest sensitivity to eutrophication (Ærteberg et al., 2002): in fact, the Po river to the North, with its high nutrient loading, determines a North-South gradient of most water quality parameters. In winter, there is a general tendency to eutrophy, extended $10 \mathrm{~km}$ offshore, which is usually rapidly removed by the water recirculation induced by storms. During summer, the eutrophic conditions are confined closer to the shore and from the Po outlet to Ravenna.

The meteorological climate consists of hot summers with occasional heavy rain and persistent high pressure, cold winters with possibly some snow and thermal inversion, rainy springs and even more rainy autumns characterised by low pressure (cyclonic circulations).

The meteomarine climate can be derived from information and measurements taken since 1983 and assuming no major shifts. Meteorological and wave observations have been made from the numerous gas platforms just in front of Ravenna: visual observations from the $\mathrm{PCB}$ platform and KNMI ships were made in the period 1971-1983, whereas measurement from AGIP platforms were performed since 1992 (IDROSER, 1996). More recently, two buoys were installed in Ancona (in 1999) on a $50 \mathrm{~m}$ depth and in Punta della Maestra (in 2002) on a $34 \mathrm{~m}$ depth by the HydroMarine National Service. The buoy in Punta della Maestra, due to interactions with ship navigation, was frequently damaged and finally removed in 2006. A new wave buoy was installed in May 2007 within Beachmed-e project (www.beachmed.eu). The buoy was placed $6 \mathrm{~km}$ offshore Cesenatico on a bottom depth of $10 \mathrm{~m}$. Acquisition system is at the Daphne oceanographic structure of Cesenatico: data are logged every $30^{\prime}$ and stored.

The tidal excursion in this area is low, in the average within the range $\pm 0.4 \mathrm{~m}$ with maximum values around $\pm 0.85 \mathrm{~m}$. Most intense events are associated with Bora (NE) and Scirocco (SE) winds with similar intensity; significant wave heights may reach 3.5 m every year and rise to $6 \mathrm{~m}$ every 100 years. Wind intensity is stronger from the shorter fetch sector of Bora (NE) where it frequently reaches 35 knots intensity, whereas from the long fetch sector of Scirocco (SE) it seldom exceeds 30 knots. The representative wind

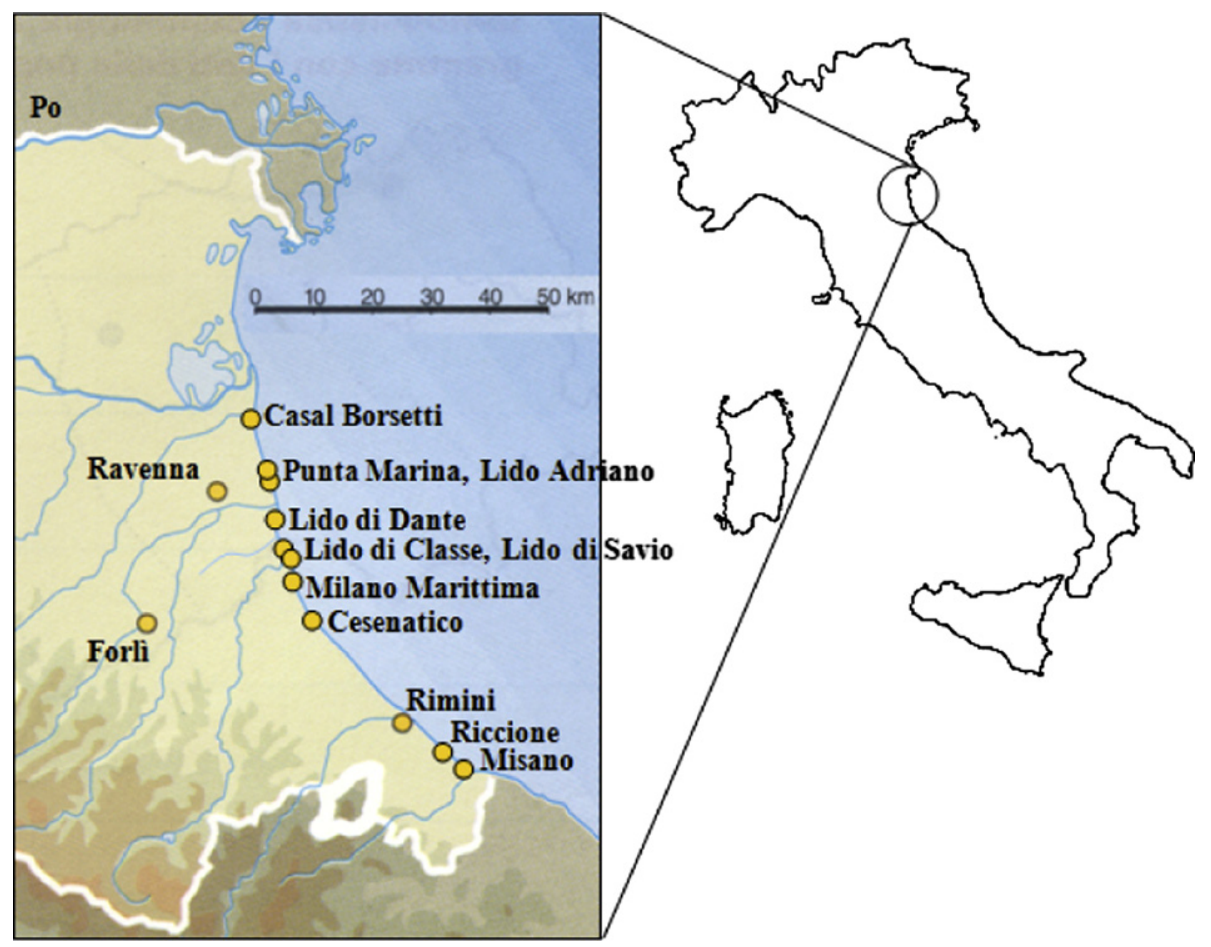

Fig. 1. Location of Emilia Romagna within Italy and position of the sites along the Emilia Romagna littoral. Scheme redrawn from Zanuttigh (2007). 
and wave climate essentially consists of steep high waves caused by Bora winds, and slightly more frequent and lower waves with milder slope caused by Scirocco winds. A quantitative detailed information on typical winds, waves and currents is provided by Preti et al. (2009) with the support of 2DH numerical simulations.

\subsection{Use of geosynthetics for coastal protection}

The use of sand bags became very popular in Emilia Romagna starting from the 80s, when they were adopted for the defence against erosion through three main types of applications: submerged barriers, revetments and protection of the foundations of bathing establishments (Pilarczyk, 2000). However, the major application of sand bags (around 100,000 units) was performed in the construction of submerged barriers placed at a distance of 200-300 $\mathrm{m}$ from the shore to maintain beach nourishment.

Inclusion of sand bag barriers among the possible alternatives for coastal protection is based on a series of site specific characteristics: low incident waves; absence of relevant surge storms; shortage of sediment stocks; requirement of full preservation of the environment.

Ten beaches, listed in Table 1, were protected in the last 25 years by submerged sand bag barriers. The site locations are shown in Fig. 1.

The "first generation" of structures, built around the 80s, were considered totally useless. Innovative modifications to the barrier cross section, to the characteristics of the sand bags and to the construction technology were introduced based on the results obtained from field monitoring, during the years 1983-1992.

Changes were so effective to induce the local operators to name the improved structures as "second generation" ones: the volume of the single bag was increased from 1 to $2 \mathrm{~m}^{3}$ and the volume of bags used for the barrier cross section also increased from 3 to approximately $6-9 \mathrm{~m}^{3} / \mathrm{m}$. The barrier distance from the shore decreased, by varying the bottom depth where the geotextile was placed from $-3.5 \mathrm{~m}$ to approximately $-2.5 \mathrm{~m}$, i.e. on the crest of the natural bar. An additional sand bag was added behind (inshore) the barrier to mitigate the scouring. Technologies for sewing, moving and placing the geotextile were refined with particular care paid to the positioning phase.

The "second generation" of structures produced fair results in stabilising the cross-shore section and have been appreciated and maintained for a decade. Half of the interventions are still in place (Table 1), from South to North, in Misano, Riccione, Milano Marittima and Casal Borsetti. In both cases of "first" and "second generation" structures, sand bags were typically made of woven High Density Polyethylene (HDPE), filled up to $85 \%$ and weight tolerance $10 \%$. The most recent interventions are actually carried out with seamless bags in woven polyamides 6.6 UV stabilised, tensile strength not less than $450 \mathrm{~N} / 5 \mathrm{~cm}$, weight $235 \mathrm{~g} / \mathrm{m}^{2}$ (source Servizio tecnico di Bacino, RER).

The monitoring of the behavior of the sand bag structures was not always sufficiently accurate to estimate the real efficacy of the geosynthetic structures, with the exception of the case study of Riccione, whose main results are detailed in the next Section.

Nevertheless, in absence of field observations, it is relevant to refer to the opinions of local administrations and coastal authorities. The performance perception is globally negative for the interventions in Punta Marina, Lido di Dante and Lido di Classe/Lido di Savio. The works in Casal Borsetti and in Milano Marittima did not produce specific criticisms, whereas the barriers in Cesenatico, Riccione and Misano got positive judgments and found the public agreement. It is common opinion that the cost-performance ratio for this kind of structures is too high, requiring a yearly nourishment to maintain the shoreline position which is only a little lower - and greater for severe erosive conditions - to the case of plain nourishment.

\section{The case study of Riccione}

\subsection{The site and the intervention}

Riccione is a famous tourist resort close to Rimini (location in Fig. 1), in the Southern part of the Emilia Romagna coast. The sandy beach of Riccione suffered from erosion induced by a severe deficit in the long-shore sediment transport. In fact $7 \mathrm{~km}$ of emerged structures were used in order to protect Cattolica, another important tourist resort placed further South. These barriers showed to be an effective protection to the local beaches, preserving the shoreline position, but induced an undesired accumulation of fine sediments due to a severe restriction of current circulations. Moreover, they intercepted the near-shore northward directed sediment transport, and thus caused erosion to the adjacent beaches.

In the Northern part of Cattolica beach, also small groins were built and, later, a $700 \mathrm{~m}$ emerged barrier system was constructed extending from the groins until the Southern boundary of the Municipality of Riccione. These protections induced strong erosion (up to 60-70 $\mathrm{m}$ of shoreline retreat) on the Southern reach of Riccione beach (approx. 600-700 m long).

In order to effectively contrast this severe erosion process and at the same time to preserve water quality, a nourishment was carried out in Riccione beach, protected by a $1000 \mathrm{~m}$ long sand bag barrier. This first barrier was based on a pioneering ("first generation") design and after around 10 years had partially sunk. For economical

Table 1

Intervention with geosynthetic barriers along the Emilia Romagna coast.

\begin{tabular}{|c|c|c|c|c|}
\hline Beach & Year & Barrier length, $\mathrm{m}$ & Nourishment, $\mathrm{m}^{3}$ & Remarks \\
\hline Casal Borsetti & $1989-1991$ & 2700 & 365,000 & $\begin{array}{l}\text { With a 2nd intervention, the barrier was connected } \\
\text { to the shore with rocky groynes. }\end{array}$ \\
\hline $\begin{array}{l}\text { Lido Adriano } \\
\text { Punta Marina }\end{array}$ & 1989-1991 & 4500 & 900,000 & $\begin{array}{l}\text { The area was already confined laterally by rocky groynes. } \\
\text { The barrier was after few years substantially replaced by } \\
\text { a rocky low crested structure. }\end{array}$ \\
\hline Lido di Dante & 1986 & 700 & 65,000 & $\begin{array}{l}\text { In less than } 10 \text { years, substituted by a composite intervention } \\
\text { with groynes, rocky low crested structures and submerged } \\
\text { connectors. Also the rocky structure was repeatedly recharged } \\
\text { (twice in } 10 \text { years). }\end{array}$ \\
\hline $\begin{array}{l}\text { Lido di Classe } \\
\text { Lido di Savio }\end{array}$ & 1989 & 500 & 35,000 & The area was already confined laterally by rocky groynes. \\
\hline Milano Marittima & 1983 & 2200 & 260,000 & $\begin{array}{l}\text { Still operating. Two groynes } 55 \mathrm{~m} \text { long, } 2 \mathrm{~m} \text { wide in } \\
\text { wood piles were added in } 2007 .\end{array}$ \\
\hline Cesenatico & 1983 & 800 & 65,000 & Substituted in about 15 years by a wider and longer rocky barrier. \\
\hline Riccione & 1983,1995 & 1000,2000 & $75,000,180,000$ & Still operating. \\
\hline Misano & 1983 & 1600 & 135,000 & Still operating. \\
\hline
\end{tabular}




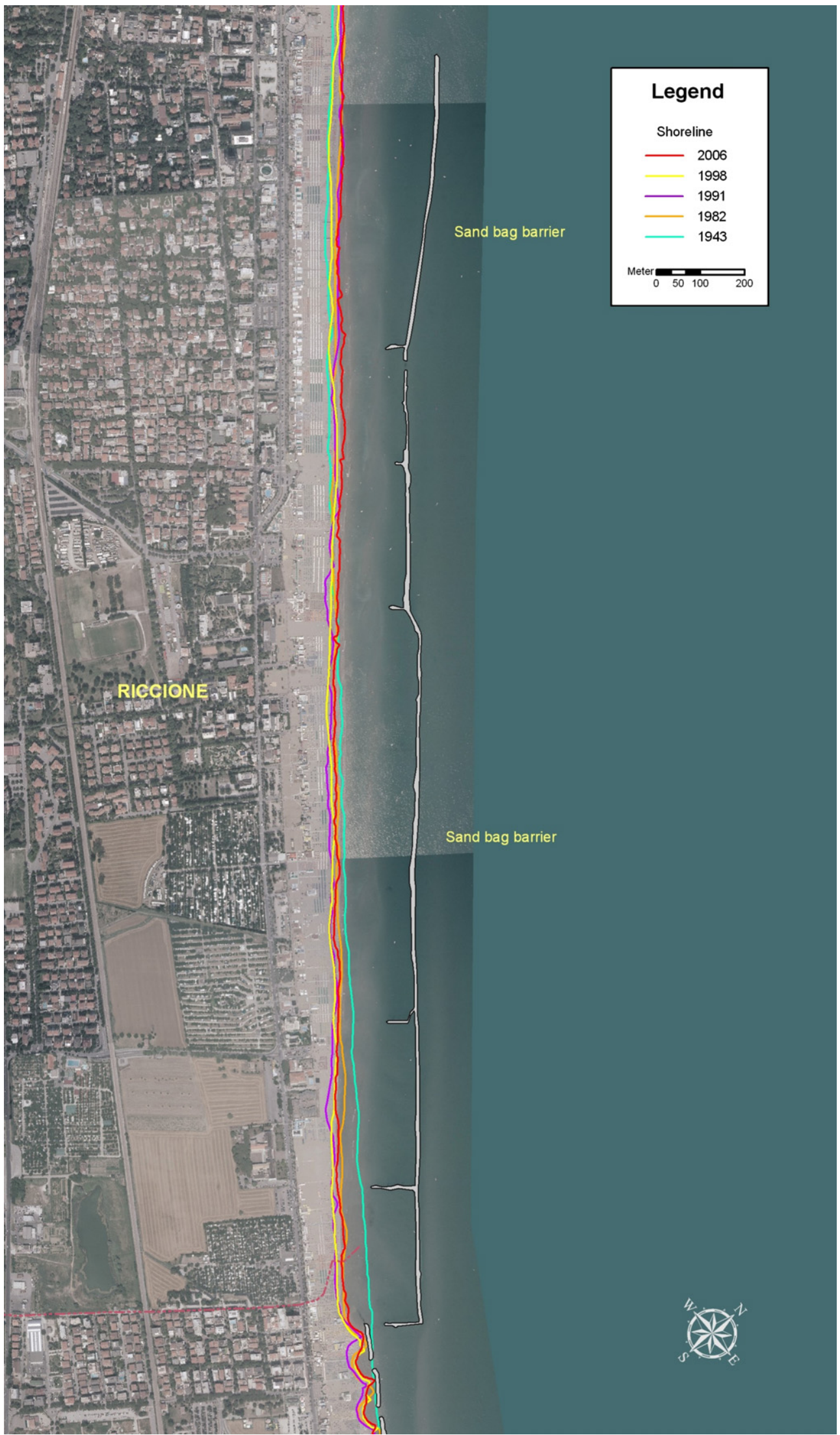

Fig. 2. Aerial view of Riccione littoral, showing the geosynthetic barrier and the shoreline evolution within the last 20 years. 


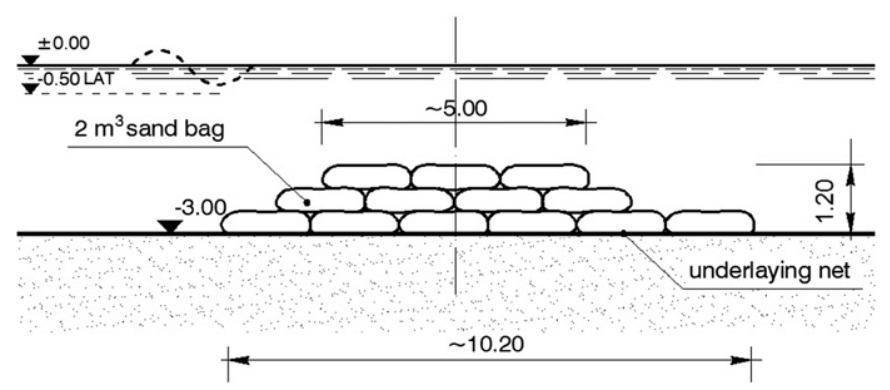

Fig. 3. Cross section of the barrier built in Riccione in 1995. reasons, beach maintenance was very limited (a single 70,000 $\mathrm{m}^{3}$ nourishment in 10 years), and beach erosion, extended Northwards, appeared again very evident 13 years after the barrier construction.

In 1995 another sand bag barrier of the "second generation" was built up (Fig. 2). The barrier characteristics are akin to those documented by Liberatore (1992) with reference to Punta Marina:

- the sand bag was of $2 \mathrm{~m}^{3}$ (approximately $3 \mathrm{~m} \times 1.7 \mathrm{~m} \times 0.4 \mathrm{~m}$ ) instead of $1 \mathrm{~m}^{3}$;

- the barrier was placed much closer to the shore (200 $\mathrm{m}$ from the shore);

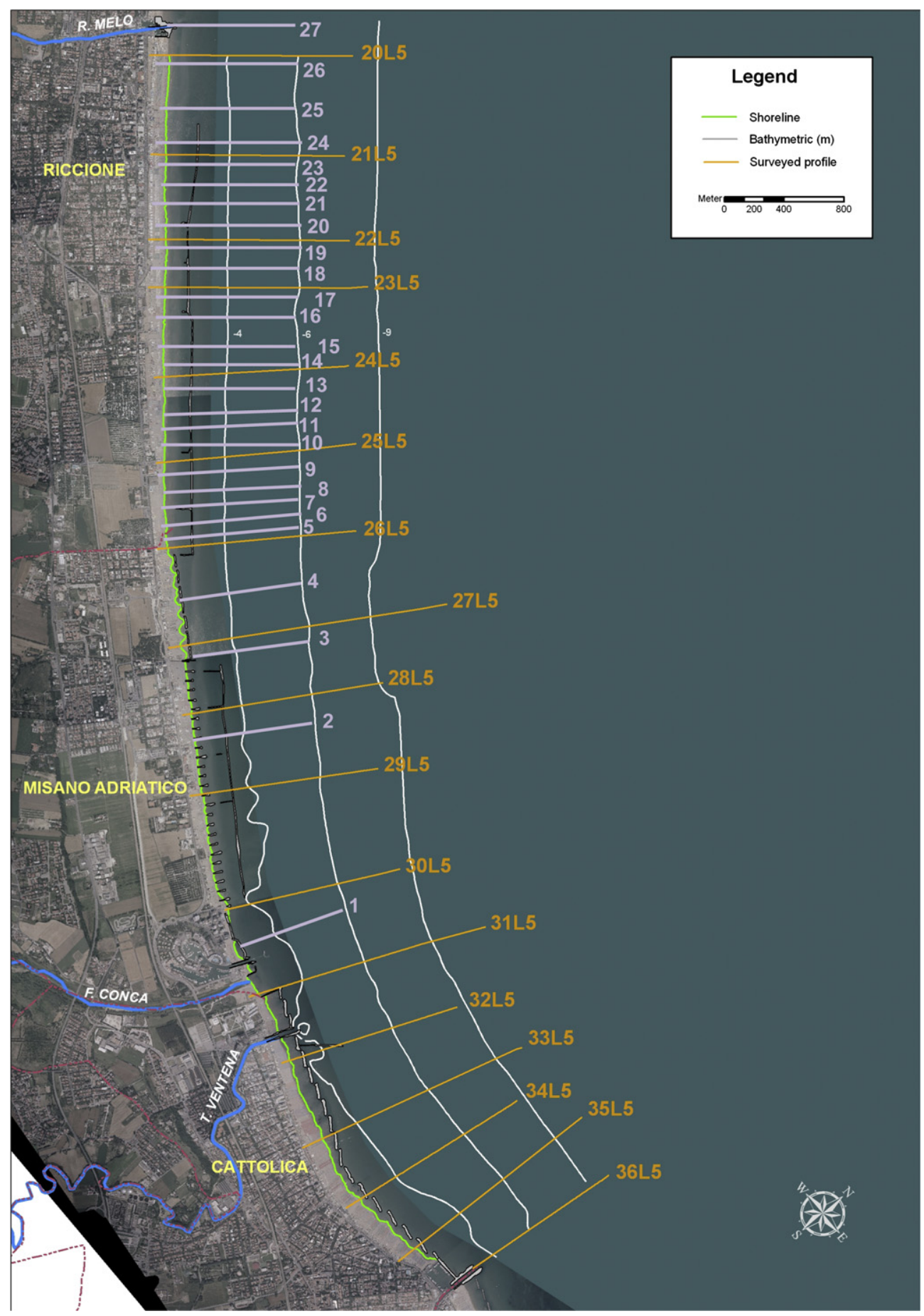

Fig. 4. Plan view of the barrier in Riccione, with indication of the surveyed profiles during both intensive and long-term monitoring. Misano barrier is also visible. 
a

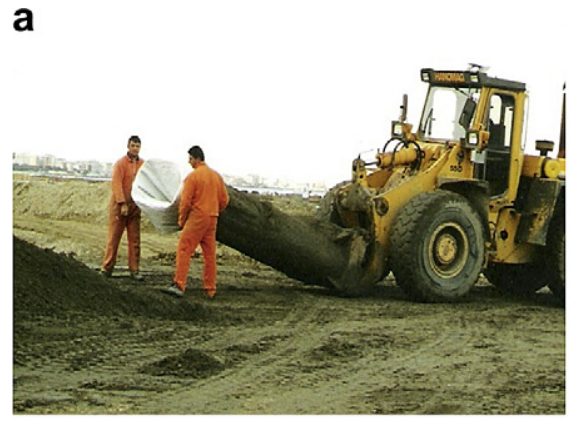

C

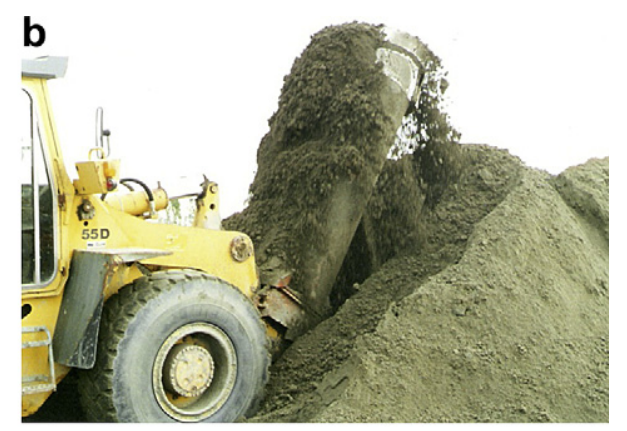

d

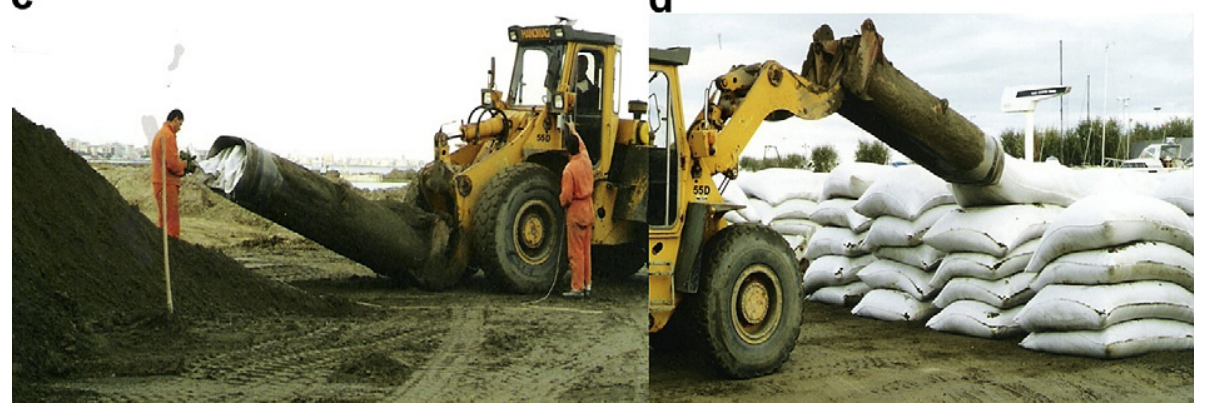

Fig. 5. Construction techniques: a) preparation of the $2 \mathrm{~m}^{3}$ sand bag, b) bag filling with nourishment sand; c) seam; d) preparation of bag stocks.

- the barrier was wider (crest width $5 \mathrm{~m}$ );

- an additional line of sand bags was placed inshore for scour protection purposes.

The barrier cross section is presented in Fig. 3 and the plan view is shown in Figs. 2 and 4. The plan disposition was designed to keep the barrier toe at an almost constant depth, which actually varies between -2.5 and $-3.0 \mathrm{~m}$ asl (crest level from -1.3 to $-1.8 \mathrm{~m}$ asl) The construction of the new barrier $3000 \mathrm{~m}$ long was coupled with a $180,000 \mathrm{~m}^{3}$ nourishment. This second barrier is still working, with 1 small maintenance recharge of sand bags in 2007 and one (with 600 bags coupled to a nourishment of $60,000 \mathrm{~m}^{3}$ ) in Spring (2010). In early Autumn 2010, an additional intervention was carried out (with 1200 bags), aiming at rising the barrier crest to a minimum of $-1.5 \mathrm{mbsl}$.

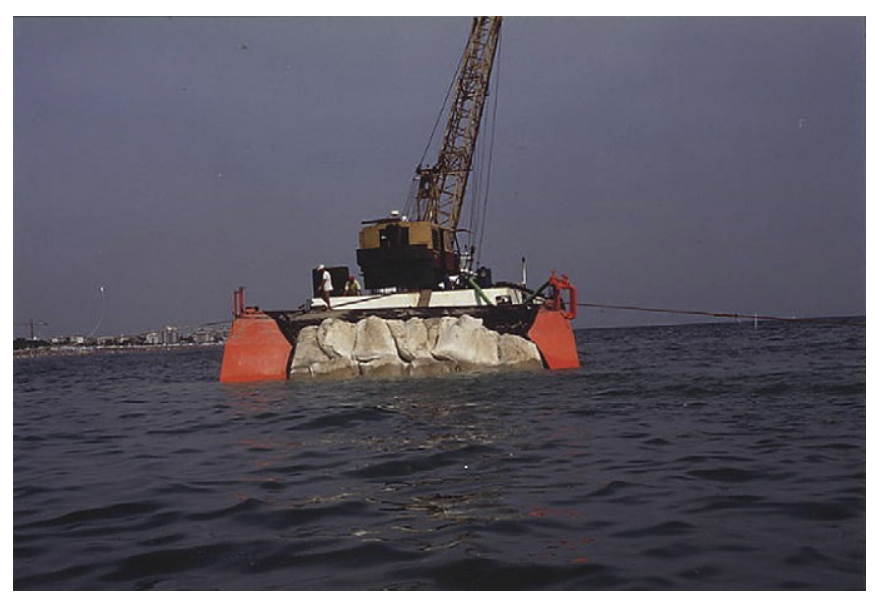

Fig. 6. Construction techniques: the geotextile and the whole cross section, sliding over a suitable slipway, are laid down from the pontoon.

\subsection{Construction technology}

The filling technique adopted for the sand bags composing the barrier in Riccione, which can be used for few or many units, is shown in Fig. 5. The filling was performed by two technicians and a machine properly equipped with a pipe. The sand bag was placed in the pipe bending the upper part of the bag (Fig. 5a) for a length properly selected to reach the desired filling level; the bag was filled (Fig. 5b), seamed (Fig. 5c) and prepared to be stocked (Fig. 5d).

The construction was carried out in three phases, starting from the South: $1600 \mathrm{~m}$ of the barrier were laid down in 1995, $400 \mathrm{~m}$ in 1996 and $1000 \mathrm{~m}$ in 2000.

The laying technology of the barrier was totally new. Instead of using a bucket, as in the past, a sort of slipway was used, so that the cross section base was prepared on board, and two rows were let slowly slide down (Fig. 6). The upper layer was placed at the end, with a special bucket. This method overcomes the disadvantage of an almost random positioning of each bag, with probable misplacement of the underlying geotextile. The bags are aligned with their length parallel to the barrier axis, and interlocking is provided by bags overlapping in such direction; the final bag seam lies in the horizontal plane.

\subsection{Eco-compatibility of the defence technique}

The high compatibility of geosynthetic materials with the surrounding environment is proven by many other similar applications worldwide (Burgess et al., 2003; Jackson et al., 2004; Thanner et al., 2006). The exposure of HDPE to seawater may lead to biofouling (Artham et al., 2009) which can cause damage to the bag surface.

In Riccione an underwater inspection was performed every year within the first three years following the barrier construction in 1995. These inspections demonstrated that algae and mussels soon populated the sand bags (Fig. 7) but did not cause damages. Moreover, the analysis of 10 water samples in 1995 and in 1997 showed that water quality remained excellent as before the works. 

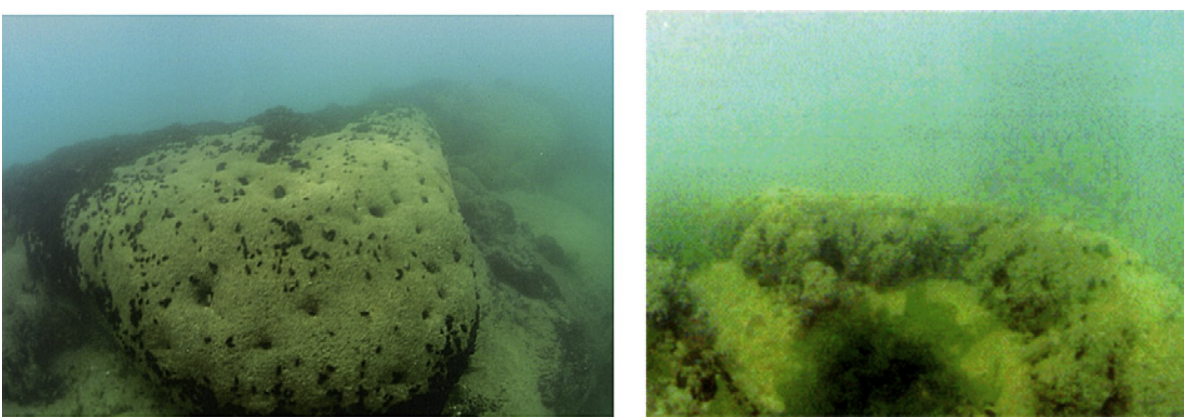

Fig. 7. Sand bags covered by polychates (to the left) and by hard seashells (mytilus gallusprovincialis, to the right).

The presence of species that usually colonise defence structures in the area (Zanuttigh et al., 2005) can be regarded as an indicator of low environmental impact of the geosynthetic barrier and at the same time an increase of species biodiversity with respect to the pre-existent soft bottom assemblages.

In this case the creation of habitat on the submerged structure does not provide any significant improvement of recreational
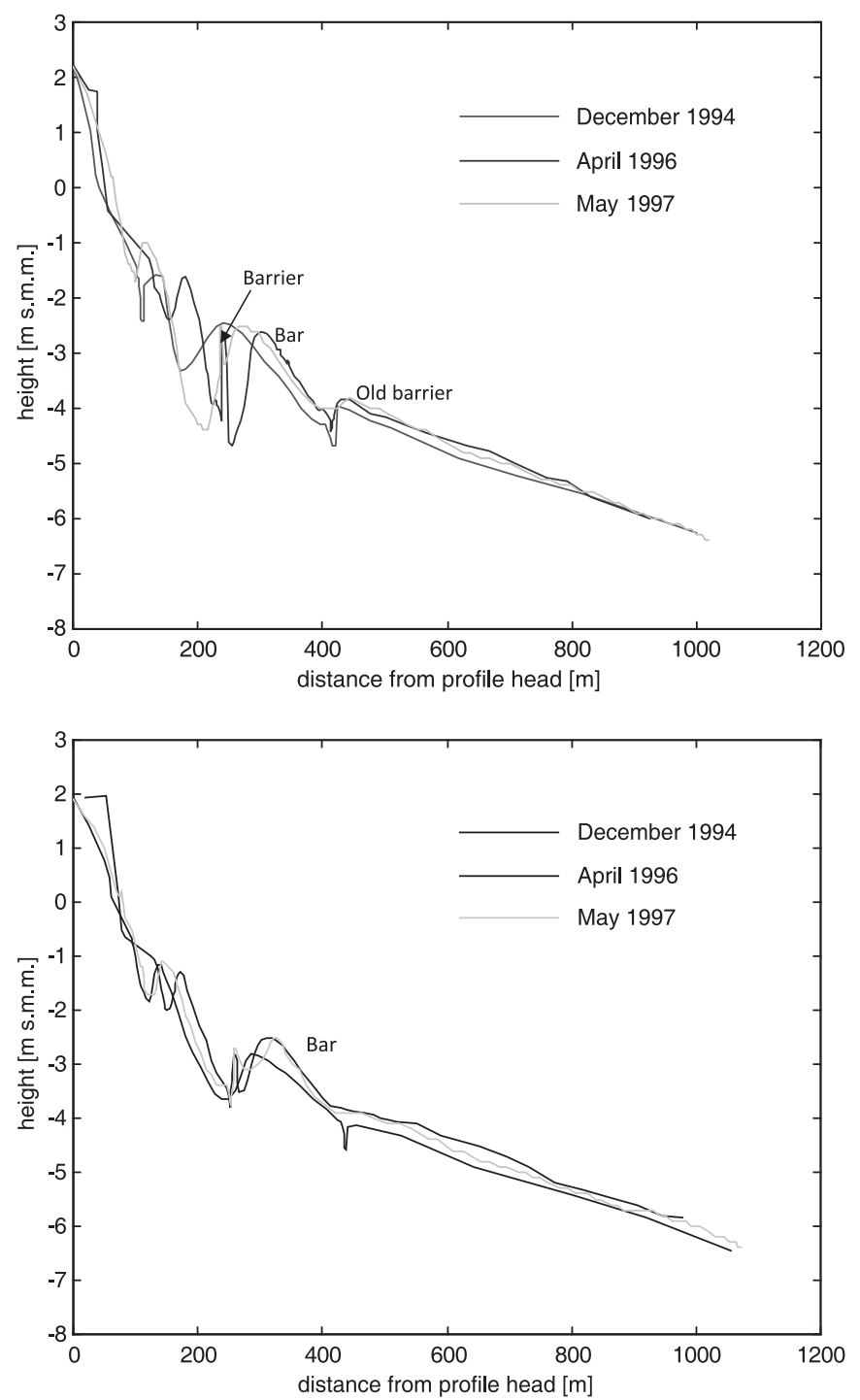

Fig. 8. Migration of the sandy bar towards the barrier, comparison of cross-shore profiles in the period 1994-1997, sections 10 (top) and 11(bottom). activities (for instance, diving within the marine park) related to the yet high diffusion of the colonizing species. The presence of mussels on the bags is not so large to justify human interaction with the barrier to catch them, action that may damage the bags.

The presence of colonizing organisms increases the barrier roughness and thus the efficiency in reducing the incident wave energy.

\subsection{Surveys of barrier stability and bottom evolution}

\subsubsection{Short-term performance of the intervention}

An intensive monitoring program started in December 1994, when a bathymetry was performed just before the construction of the first $2000 \mathrm{~m}$ of barrier, and ended in May 1997.

The bathymetric surveys of the area, performed in December 1994, April 1996 and May 1997, consisted of 30 cross-shore profiles (position in Fig. 4), mainly concentrated in the zone of the intervention. Few profiles were also surveyed $2 \mathrm{~km}$ Southwards (till the barriers of Cattolica), and $3 \mathrm{~km}$ Northwards (just $1 \mathrm{~km}$ beyond Riccione harbor). The monitoring is relative to the first $2000 \mathrm{~m}$ of barrier, placed between profile 5 and 18. The $1000 \mathrm{~m}$ barrier covered by the profiles 19 to 25 was added in 2000 , after the results of the monitoring program.

Along 10 of the 30 bathymetric profiles, 50 sediment samples were collected and analysed for determining the grain size distribution both in December 1994 and in May 1997. The foreshore grain size is in the range $0.18-0.25 \mathrm{~mm}$; at water depths between 0 and $-4 \mathrm{~m}$, the diameter is in the range $0.125-0.18 \mathrm{~mm}$; below $-4 \mathrm{~m}$, the mean grain diameter is smaller than $0.125 \mathrm{~mm}$.

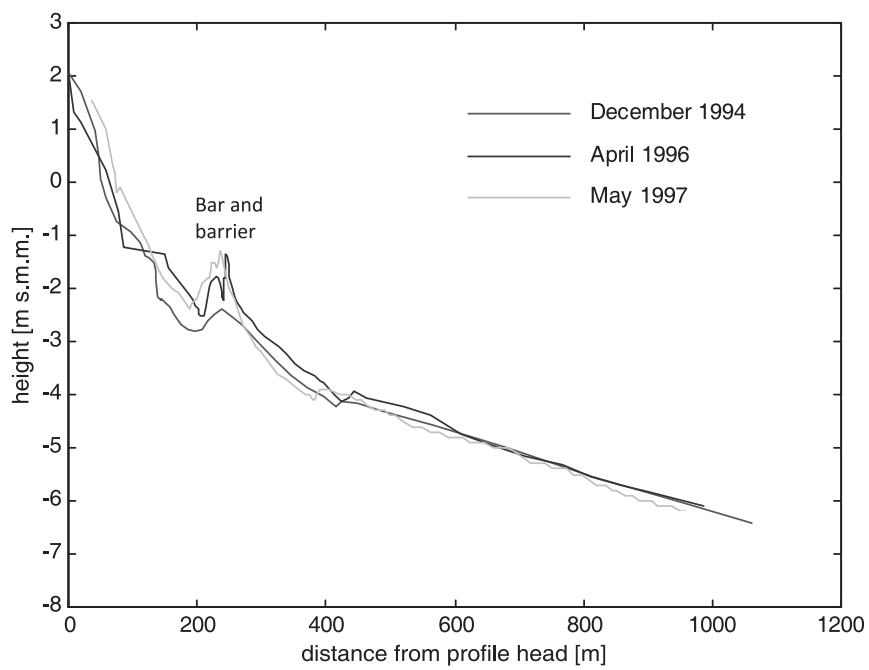

Fig. 9. Stability of the barrier, comparison of cross-shore profiles in the period 1994-1997, section 6 
During the monitoring around 10 storms with breaking point placed offshore the barrier occurred in the area. The major storm occurred between 22 and 25 Dec 1996, with maximum significant wave height $\left(H_{\mathrm{so}}\right)$ equal to $4.8 \mathrm{~m}$, exceeding $3 \mathrm{~m}$ for $60 \mathrm{~h}$. The last storm before the May 1997 survey occurred less than 1 month earlier, with $H_{\text {so }}$ equal to $3.4 \mathrm{~m}$ coupled to high tide of $0.5 \mathrm{~m}$.

Comparisons among cross-shore profiles are shown in Figs. 8 and 9. The position of the old barrier constructed in 1983 is still visible in the profile of 1994, while it is partially sunk and covered by sand in the more recent profiles, thanks to the strong accretion visible in the offshore zone.

The artificial barrier apparently stabilised the position of the natural bar, although with a different benefit along the beach. The barrier was laid along a straight line, regardless of the real position of the underlying natural bar. The base of the barrier was then placed at different heights, varying from $-2.5 \mathrm{~m}$ to $-4.1 \mathrm{~m}$, sometimes on the top of the natural bar, sometimes exactly in the trough behind it. This situation was observed in April 1996, one year after the construction, while in May 1997 the profile showed that the bar had always moved almost exactly over the artificial barrier.

Where the artificial barrier was placed in the trough in front of the natural bar, the existing natural bar slowly migrates over it, see the profiles in Fig. 8.

The barrier results more efficient when it is placed exactly on top of the existing bar see the profiles in Fig. 9, because of the greater concentration of wave breaking over the barrier and consequently the greater dissipation of incident wave energy. Fig. 9 shows the formation of a deep trough on the barrier inshore crest and considerable accretion at the barrier seaward crest. The submerged barrier looks like a natural bar, with the exception that its inshore slope is steeper. This steep front can be interpreted if one considers that the sand in the barrier trough is unstable because of turbulence induced by wave breaking and would be naturally carried offshore, producing a bar migration. Indeed the sand bags do not move, thus avoiding offshore barrier migration and leading to a deep trough in front of it. This picture is fairly different from those typical of other low crested barriers (Burcharth et al., 2007) which are dominated by piling up (see Zyserman et al., 2005; Martinelli et al., 2006). In case of the sand bag barrier, piling up accordingly to the prediction model by Zanuttigh et al. (2008) is of the order of just few centimeters $(0.1-2 \mathrm{~cm})$, due to the low barrier height and the important return flux over the barrier crest. Consequently the long-shore currents driven by piling up are not significant.

The comparison among the measured profiles is synthesized in Fig. 10 in terms of volume variations for each cell defined by two adjacent profiles. Along the monitored beach $(\cong 3.5 \mathrm{~km})$, the offshore zone is everywhere in accretion on average of $40 \mathrm{~m}^{3} / \mathrm{m}$, but the accretion occurs in an area far from the shoreline where mainly fine material is present. For the profiles 21-29, there is a marked tendency to erosion in the first $200 \mathrm{~m}$ from the shore (up to the position of the barrier), with the loss of almost half of the nourished material (44\%). In case of the profiles 1-20 the global tendency is to accretion also inshore the artificial barrier.

According to Fig. 10 the short term performance of the barrier is quite effective, since the nourishment is severely eroded only in the Northern barrier reach and indeed the loss of some of the nourished material is natural.

Some specific effects induced by the barrier can be found from the evident correlation between the height of the barrier crest with the accretion per unit length measured from the shore to the barrier position, see Fig. 11. Where the barrier is placed at depths lower or equal to $3.7 \mathrm{~m}$ (that means crest level around $-2.5 \mathrm{~m}$ s.w.l.) there is only accretion or modest erosion, whereas the nourishment is lost where the barrier is placed below $-3.7 \mathrm{~m}$.

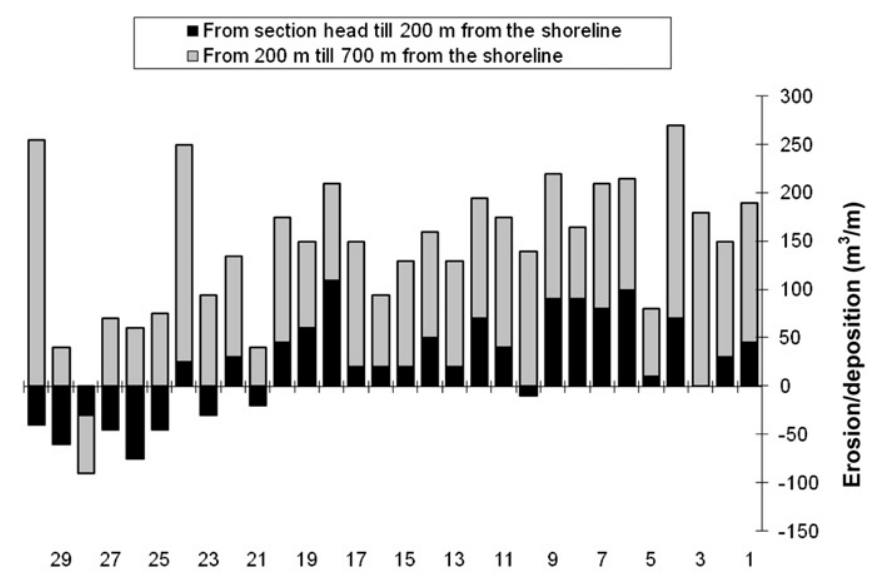

Number of the surveyed cross-shore profile

Fig. 10. Eroded or deposited volumes per unit length across the barrier in Riccione during the period December 1994-May 1997. Numbers on the abscissa refer to the numbers of the cross-shore profiles identified in the plan view in Fig. 4; profiles 28 and 29 that do not appear in Fig. 4 are placed Northwards of the Melo river mouth.

\subsubsection{Long-term performance of the intervention}

Since the end of the intensive monitoring program, periodic bathymetric surveys were performed across the barrier along 6 selected profiles, allowing to reconstruct bottom evolution and barrier position from the construction till 2006 (see the position of the profiles in Fig. 4 and the labels in Fig. 12). A recent multi-beam survey was carried out in the area to verify the placement and the integrity of the bags (Fig. 13).

Fig. 12 shows the superposition of the six surveyed profiles. Each profile was leveled four times:

- In 1983, some years before the building of the sand bag barrier;

- In 1993, just before the building;

- In 2000, few years after the intensive monitoring program described in the previous Sub-section, just after the building of the remaining $1000 \mathrm{~m}$ of barrier;

- In 2006, the last available information.

The barrier is visible for the first time in the 2000 survey. It is placed at a distance of approximately $250 \mathrm{~m}$ from the profile head section, which marks the origin for the horizontal distances. It can

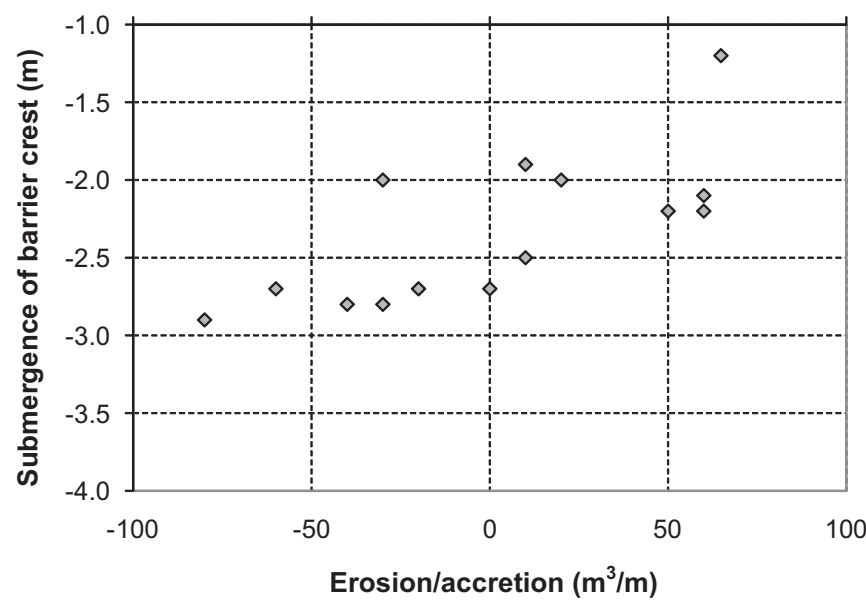

Fig. 11. Submergence of the barrier crest VS average accretion (positive) or erosion (negative) measured between the shore and the barrier. 

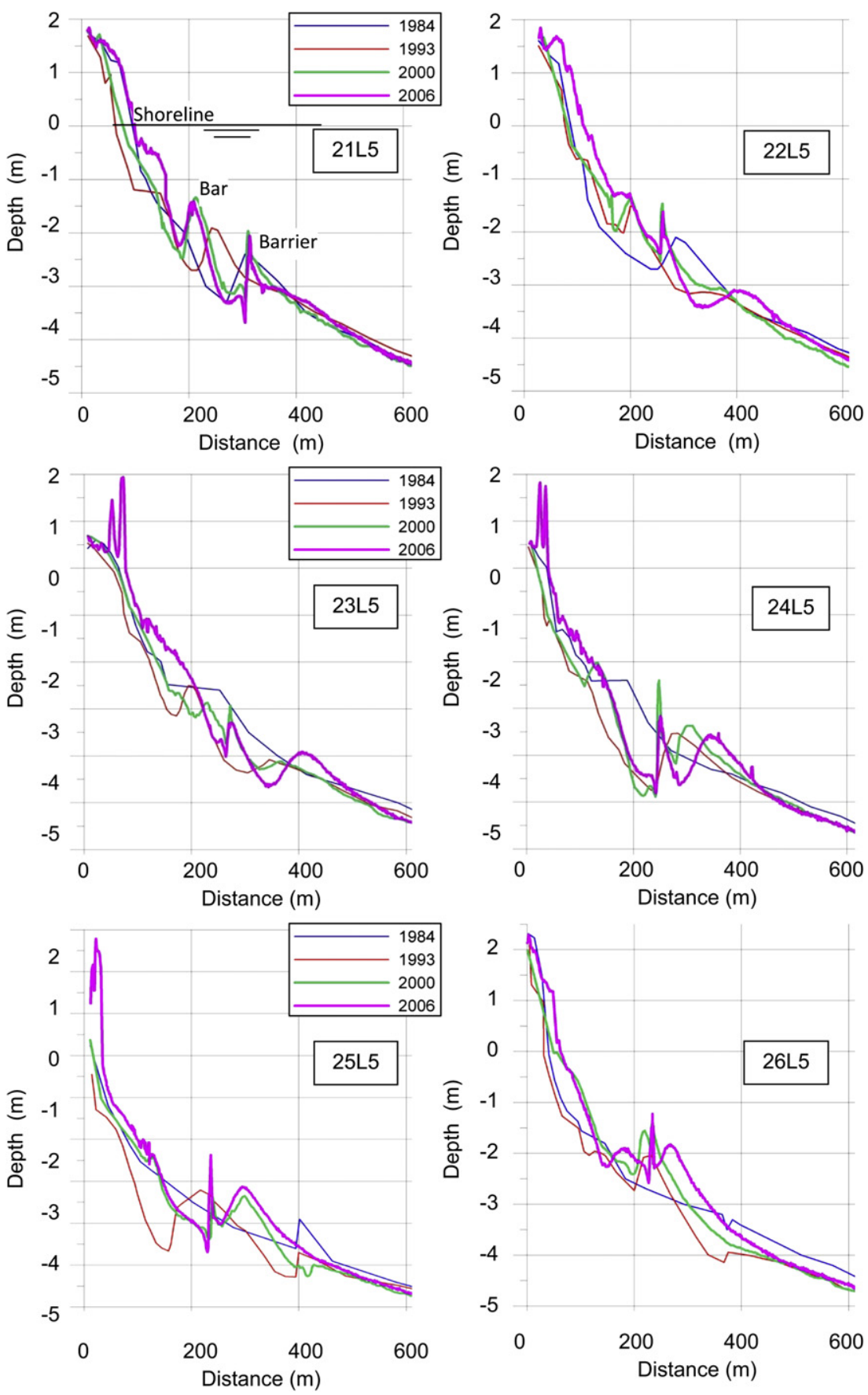

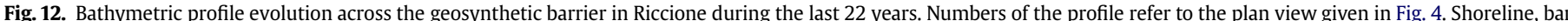
and barrier position can be easily identified (see example in the top left graph).

be easily identified, since the profile has an abrupt change in height, with very steep fronts. The barrier is consistently present also in the 2006 survey, showing that it has not collapsed.

The comparison between the 1983 and 1993 surveys shows that the natural bar is very mobile, since it has moved in all profiles. The comparison between the 2000 and 2006 surveys confirms that after the barrier construction, the beach cross-shore profile is stable, since in all the six cases it did not move.

The barrier is placed on top of the bar crest in profiles 26 and exactly inside the bar trough in profile 21 and, to a lower extent, in profiles 23 and 24. Profiles 22 and 25 are intermediate cases. The relative position between the barrier and the pre-existing natural bar can be easily verified by comparing the bar crest in 1993 and the barrier position. Where the barrier is placed close or on the crest of the existing bar, i.e. at the higher possible position, the structure is presumably capable of interfering more effectively with the waves and induces breaking. Consequently a single natural bar tends to form in proximity of the barrier, adjoining its seaward slope (see profile 26). In the other cases, also other natural bars develop, possibly inshore the artificial barrier (see profile 21 ).

In conclusion, the long-term morphodynamic evolution (6 and 12 years after construction) confirms the tendency already seen in 


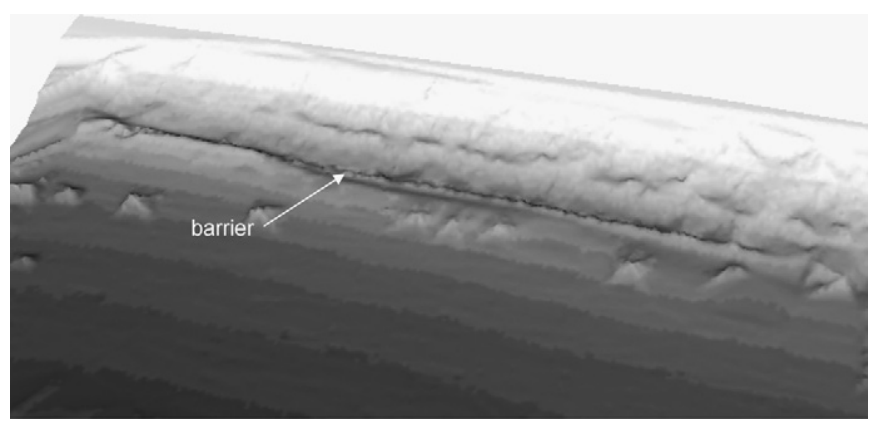

Fig. 13. Rendering of the last multi-beam bathymetric survey of Riccione barrier, 2008 Gray colour scales down every $0.5 \mathrm{~m}$, lightest colour denotes emerged beach $(+1.0 \mathrm{~m})$ and darkest colour the deep bottom $(-5.5 \mathrm{~m})$.

the first 4 years monitoring. It is interesting to note that model investigations specifically performed at Delft Hydraulics (Wouters, 1988) predicted a morphological behavior rather different from the surveys. It was observed erosion seaward and accumulation inshore the barrier. The barrier behavior was thus erroneously interpreted as an offshore berm for the sand nourishment.

Barrier integrity in 2006, i.e. 8 years after the building, is entirely proved by the 2006 multi-beam survey shown in Fig. 13 .

It may happen that the barrier is completely covered under a natural bar, thus apparently disappearing, and for this reason it is generally believed to be of short life; should the natural bar slightly move, the barrier would become visible again. The presence of some gravel on the beach immediately after construction suggests that some bags (which were filled with gravel rather than sand) actually break in this phase, but this seems to involve a minor percentage.

Based on submerged inspections and on bathymetries, the bags of the barrier are durable and their covering seldom break after construction: even the bag of the old barrier (built in 1983) were found undamaged, but partially sunk. Polymers resistance to aging in a marine environment is well known (Guidetti et al., 1996), and actually HDPE is considered to be the best choice because it provides a good compromise in terms of performance/cost (Guermazi et al., 2009).

\section{Conclusions}

Many interventions performed in the last 25 years along the Emilia Romagna littoral included the use of sand bag barriers. The "first generation" of sand bag was not sufficiently resistant, mainly due to improper handling at construction phase, dimensions of the bags and cuts operated by mussel fishermen (Liberatore, 1992). Except for this latter possible shortcoming, the second generation of sand bag barriers addressed all possible causes of weaknesses so that some of these interventions are still operating without additional placement of hard structures.

The cross-shore profiles, documented for the beach of Riccione (and summarized in Fig. 12), show the presence of the second generation barrier wherever it was built. In few cases the first generation barrier cannot be seen because the natural bar moved and covered the structure. From multi-beam bathymetries (such as in Fig. 13) no evident damage to the barrier was spotted. A slight sinking of the structure is reported in many places, though, so that maintenance is necessary. Therefore the existing data support a good durability of the overall structure.

Sand bags were colonized by many species typical of non-soft bottom habitats and such colonization contributed to increase the structure roughness, leading to greater dissipations and hydraulic characteristics similar to a rubble mound.
With respect to efficiency, the protection resisted to a very strong storm surge in December 1996, with small recessions of the coastline. The analysis of field surveys proves that the barrier stabilised the position of the natural bar, and therefore the beach cross-shore profile, when it is built on top of the existing natural bar. It is reasonable that the bar stabilisation contrasted the erosive tendency. Indeed Pruszak et al. (1997) proved that bar size and shape depend on stability of wave breaking position during bar formation. According to Kriebel and Dean (1985), bars tend to self maintaining by forcing waves to break on them. This is the typical condition of submerged barriers, that are higher than natural bars, thus being more effective in producing wave breaking, and are stable against long-shore and cross-shore currents (Jacobs and Kobayashi, 1983; Kobayashi and Jacobs, 1985).

\section{Acknowledgments}

The support of the EU FP7 Theseus "Innovative technologies for safer European coasts in a changing climate", contract ENV.2009-1, $\mathrm{n}^{\circ} 244104$, is gratefully acknowledged.

\section{References}

Ærteberg, G, Carstensen, J., Dahl, K., Hansen, B., Rygg, K, Sørensen, G., Severinsen, K. Nygaard, W., Schrimpf, Ch. Schiller, Druon, J.-N., Casartelli, S., 2002. Eutrophication in European Coastal Waters. Topic Report n. 7/2001. EEA, Copenhagen, pp. $1-86$.

Alvareza, E., Rubio, R., Ricalde, H., 2007. Beach restoration with geotextile tubes as submerged breakwaters in Yucatan, Mexico. Geotextiles and Geomembranes 25, 233-241.

Artham, T., Sudhakar, M., Venkatesan, R., Madhavan Nair, C., Murty, K.V.G.K., Doble, M., 2009. Biofouling and stability of synthetic polymers in sea water. International Biodeterioration \& Biodegradation 63 (7), 884-890.

Burcharth, H.F., Hawkins, S., Zanuttigh, B., Lamberti, A., 2007. Environmental Design Guidelines for Low Crested Coastal Structures. Elsevier.

Burgess, S.C., Black, K.P., Mead, S.T., Kingsford, M.J., 2003. Considerations for Artificial Surfing Reefs as Habitat for Marine Organisms, Proceedings of the 3rd International Surfing Reef Symposium, Raglan, New Zealand, pp. 289-302.

Guidetti, G.P., Rigosi, G.L., Marzola, R., 1996. The use of polypropylene in pipeline coatings. Progress in Organic Coating 27, 79-85

Guermazi, N., Elleuch, K., Ayedi, H.F., 2009. The effect of time and aging temperature on structural and mechanical properties of pipeline coating. Materials \& Design 30 (6)

IDROSER, 1996. Progetto di piano per la difesa dal mare e la riqualificazione ambientale del litorale della Regione Emilia Romagna Bologna. (in Italian).

Jackson, L.A., Reichelt, R.E., Restall, S., Corbett, B., Tomlinson, R.B., McGrath, J., 2004. Marine Ecosystem Enhancement on a Geotextile Coastal Protection Reef Narrowneck Reef Case Study. Proc. 29th Int. Conf. Coastal Eng.

Jacobs, B.K., Kobayashi, N., 1983. Sandbag Stability and Wave Run-Up on Bench Slopes. Univ. of Delaware, Dept. of Civil Engineering. Report No CE 86-36.

Kobayashi, N., Jacobs, B.K., 1985. In: Magoon, O.T., et al. (Eds.), Experimental Study on Sandbag Stability and Runup. Coastal Zone '85, vol. 2. ASCE, New York, pp. 1612-1626.

Kriebel, D.L., Dean, R.G., 1985. Numerical simulation of time-dependent beach and dune erosion. Coastal Engineering 9 (Elsevier, Amsterdam)

Liberatore, G., 1992. Detached Breakwaters and Their Use in Italy Proc. Short Course on Design and Reliability of Coastal Structures. 23rd Int. Conf. On Coastal Engineering, Venice, Italy.

Martinelli, L., Zanuttigh, B., Lamberti, A., 2006. Hydrodynamic and morphodynamic response of isolated and multiple low crested structures. Experiments and simulations. Coastal Engineering 53 (4), 363-379.

Martinelli, L., Zanuttigh, B., Corbau, C., 2010. Assessment of coastal flooding hazard along the Emilia Romagna Littoral, IT. Coastal Engineering 57 (11-12), 1042-1158.

Pilarczyk, K.W., 2000. Geosynthetics and Geosystems in Hydraulic and Coastal Engineering. Balkema, Rotterdam, p. 913.

Plan Bleu, 2008. Les perspectives du Plan Bleu sur le développement durable en Méditerranée. www.planbleu.org/publications/RapportActivites2008Uk.pdf.

Preti, M., Lamberti, A., Martinelli, L., Albertazzi, C., Sammarini, S., 2005. An Effort toward Renaturalisation of Igea Marina Beach. Transformation of 6 Emerged Barriers into a Single Low Crested Structure, Proc. MedCoast, pp. 919-930.

Preti, M., De Nigris, N., Morelli, M., Monti, M., Bonsignore, F., Aguzzi, M., 2009. Stato del litorale emiliano-romagnolo all'anno 2007 e piano decennale di gestione. I quaderni dell'ARPA, Bologna (in Italian, abstract in English)

Pruszak, Z., RoZynski, G., Zeidler, R.B., 1997. Statistical properties of multiple bars. Coastal Engineering 31 (1-4), 263-280. 
Recio, J., Oumeraci, H., 2007. Effect of deformations on the hydraulic stability of coastal structures made of geotextile sand containers. Geotextiles and Geomembranes 25, 278-292.

Ruol, P., Matteotti, G., 2004. L'impiego dei geosintetici nelle opere di ingegneria marittima e costiera. L'ingegnere e l'architetto vol. 10/2003 (in Italian).

Saathoffa, F., Oumeraci, H., Restall, S., 2007. Australian and German experiences on the use of geotextile containers. Geotextiles and Geomembranes 25, 251-263.

Shina, E.C., Ohb, Y.I., 2007. Coastal erosion prevention by geotextile tube technology. Geotextiles and Geomembranes 25, 264-277.

Thanner, S.E., McIntosh, T.L., Blair, S.M., 2006. Development of benthic and fish assemblages on artificial reef materials compared to adjacent natural reef assemblages in Miami-Dade County, Florida. Bulletin of Marine Science 78, 57-70.
Wouters, J., 1988. Stability of Geosystems. Delft Hydraulics. Report H 1930 in Dutch. Zanuttigh, B., 2007. Numerical modeling of the morphological response induced by low-crested structures in Lido di Dante, Italy. Coastal Engineering 54 (1), 31-47 (Elsevier).

Zanuttigh, B., Martinelli, L., Lamberti, A., Moschella, P., Hawkins, Marzetti, S. Checcherelli, V.U., 2005. Environmental design of coastal defence in Lido di Dante, Italy. Coastal Engineering 52 (10-11), 1089-1125.

Zanuttigh, B., Martinelli, L., Lamberti, A., 2008. Wave overtopping and piling-up at permeable low crested structures. Coastal Engineering 55 (6), 484-498.

Zyserman, J.A., Johnson, H.K., Zanuttigh, B., Martinelli, L., 2005. Analysis of far-field erosion induced by low-crested rubble-mound structures. Coastal Engineering 52 (10-11), 977-994. 